Historic, Archive Document

Do not assume content reflects current scientific knowledge, policies, or practices. 



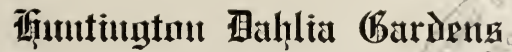

HUNTINGTON, N. Y.

CHOICE NEW VARIETIES

\section{DAHLIAS FOR 1928}

NATHAN HALE-A rich bronze decorative of great depth and perfect formation of bloom. The plant has vigorous healthy habits of growth and is immune from disease. While it is excellent for exhibition it is also one of our most valued cutting varieties owing to its long strong stems and exceptional keeping qualities. We can recommend Nathan Hale as one of the most reliable and satisfactory of up-to-date dahlias. Tubers $\$ 10.00$ each. Plants $\$ 5.00$.

ORPIN-This beautiful decorative might well have been named Sagamore, Jr. but we decided to give it a name descriptive of its color. Of the same general golden color as Sagamore, its great charm lies in a deeper, richer shading at the center. Its habit of growth is excellent and the flowers are carried on long straight stems. Tubers $\$ 10.00$ each. Plants $\$ 5.00$ each.

YELLOW BIRD-A large decorative of good form and of deep rich golden yellow very similar to Yellow de Luxe. It has a good stem and healthy strong plant growth. Its size and depth of bloom combined with unusually rich coloring make it a most desirable exhibition variety. Tubers $\$ 10.00$ each. Plants $\$ 5.00$ each.

SPECIAL OFFER-One tuber of each of the three new varieties listed above for $\$ 25.00$ net. Plants $\$ 12.50$ net.

SAGAMORE-Universally known as one of the most satisfactory dahlias to grow for any purpose. Second to none as an exhibition dahlia, Sagamore has also made a great reputation as a cut flower variety. Its keeping qualities are unexcelled and its rich golden yellow with deeper shadings at the center makes a lovely autumn decoration. Tubers $\$ 2.00$ each.

ROSEATA-If there were room for but one dahlia in the garden, there is no variety that can give as great satisfaction and charm you as much as Roseata. The blooms have great size and are a pleasing pink in color which becomes suffused with salmon and gold as the season progresses. It blooms untiringly and is at its best when frost comes. Its individual habit of growth and the unusual keeping qualities of the blooms add to its value. It is unexcelled for either cutting or for the exhibition table. Tubers $\$ 5.00$ each. Plants $\$ 2.50$ each.

MERVEILLEUX - For exhibition purposes or as a garden variety this huge perfectly formed decorative is unsurpassed. The color is a very pleasing shade of rose pink. The bush is exceptionally sturdy but somewhat dwarf and the immense, heavy blooms are held perfectly erect on sturdy cane-like stems. Tubers $\$ 3.50$ each.

MISS NEW YORK -Huge in size and spectacular in type and color, this great wavy petaled hybrid-cactus is distinctly an exhibition variety. The color is a rich rose showing rosaline purple on the reverse of the artistically twisted petals. Tubers $\$ 3.50$ each.

PRINCE OF INDIA-Very appropriately named, this beautiful rich dark red decorative hints at mystery as its name might imply. The bloom is large and well formed and is excellent for exhibition. It is a very prolific bloomer. Tubers $\$ 5.00$ each. Plants $\$ 2.50$ each.

KIRBY'S ATTRACTION-A hybrid-cactus of exceptional merit due to its excellent habit of growth and form of bloom. Its beautiful lavender pink color and its good keeping qualities make it a most desirable variety. Tubers $\$ 2.50$ each.

Ambassador, C.,.................\$1.50

Amelita, Dec., ....................... 2.00

Ben Wilson, Dec., . . . . . . . . . . . . . . . 1.00

Champagne, Dec., . . . . . . . . . . . . . . . 1.50

Earl Williams, Dec., . . . . . . . . . . . . . . . 1.00

El Dorado, Dec., . . . . . . . . . . . . . . . . . 3.00

Ellinor Vandeveer, Dec., . . . . . . . . . . . . 2.00

Elodie, C., ....................... 2.50

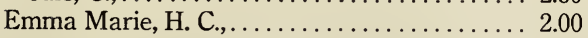

Francis Lobdell, H. C., . . . . . . . . . . . . . . 1.50

Gladys Sherwood, H. C., . . . . . . . . . . . 1.00

Hubert Badetty, H. C.,................. 2.50

Hunter's Moon, H. C., . . . . . . . . . . . . . . 1.00

Jersey's Beacon, Dec., . . . . . . . . . . . . . . . . . 3.50

Jersey's Beauty, Dec., . . . . . . . . . . . . . . . 1.50

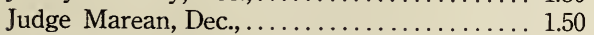

Lady Helen, H. C., .................... 1.00

Madeleine Badetty, Dec.,. . . . . . . . . . . . 5.00

Margaret Masson, Dec., . . . . . . . . . . . . . 2.50

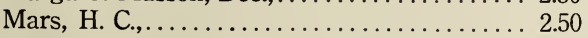

TERMS-Cash with order. Retail orders will be shipped by express or parcel post prepaid. On orders of $\$ 5.00$ or over $20 \%$ extra in tubers will be given. Your own choice if stock is available. Please order from this list as this is our final spring offering.
Mrs. I. de ver Warner, Dec.,..........\$1.00

Mrs. John Sheepers, Dec., ............. 1.50

Orpheus, P. D.,....................... 1.50

Prem. G. Clemenceau, C., . . . . . . . . . . . 2.50

Red Wing, Dec.,...................... 1.00

Robert Treat, Dec., .................. 1.50

Roman Eagle, Dec., . . . . . . . . . . . . . . . 3.00

Rookwood, Dec., .................... 2.50

Rosa Nell, Dec., ... . . . . . . . . . . . . . 1.00

Shudow's Lavender, Dec., . . . . . . . . . . . . . . 2.00

Snowdrift, Dec., . . . . . . . . . . . . . . . 1.00

Target Rock, Dec.,. . . . . . . . . . . . . . . . . . . 2.00

The Grizzly, Dec., . . . . . . . . . . . . . . 1.00

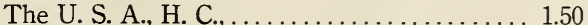

Trentonian, Dec., .................. . 3.00

White Sister, Dec.,. . . . . . . . . . . . . . . 3.00

Wizard of $\mathrm{Oz}, \mathrm{H}$. C., .............. 3.00

Wm. Slocombe, Dec.,..................... 1.00

Yellow de Luxe, Dec.,................ 5.00 
(1) 